\title{
Application of zeolites as fillers in mix asphalt
}

\author{
Agnieszka Woszuk ${ }^{1}$, Lidia Bandura ${ }^{2}$, Rafał Panek ${ }^{3}$ \\ ${ }^{1}$ Chair of Roads and Bridges, ${ }^{2}$ Chair of Geotechnology, ${ }^{3}$ Faculty of Building Engineering \\ and Architecture, Lublin University of Technology, \\ email: a.woszuk@pollub.pl,l.bandura@pollub.pl,r.panek@pollub.pl
}

\begin{abstract}
The aim of this paper is estimation of the effect of zeolites addition on properties of asphalt and examination of possible application of zeolites in mix asphalt as a filler. The addition of zeolites to the mix asphalt is one of the ways used for reduction of technological temperatures by asphalt foaming. At the same time the zeolite material replaces the filler. The paper presents the results of studies on the synthetic zeolite $\mathrm{NaP} 1$, natural zeolite- clinoptilolite and mineral filled.
\end{abstract}

Keywords: zeolite, warm mixed asphalt, mineral filler, mineral filled asphalt.

\section{Introduction}

Zeolites are aluminosilicates of skeleton structure in which void spaces formed as chambers and channels occur. Their characteristic feature is ability to accumulate in the void spaces the crystalline structure so called zeolite water which can be removed by heating and then again absorbed or replaced by other substances. Such specific internal structure imparts many physical and chemical features to zeolites which are of significant importance in a large variety of industrial applications $[1,2,3]$.

One of the latest possibilities in applications of zeolites for production of mineral and asphalt mix for asphalt foaming and technological temperature reduction. The hitherto investigations of mix asphalt with the addition of zeolites dealt mainly with synthetic zeolites in the patented technologies Aspha-Min and Advera. According to the producers recommendations of the agent reducing temperature of production and compaction- the zeolite Aspha-min ${ }^{\circledR}$ replaces the filler in the warm mix asphalt (WMA) procedure and it should be evidenced as a filler in the investigations [4,5].In this technology zeolite is mass batched in the amount of $0,3 \%$ in relation to the WMA mass [6,7]. Also in the case of alternative materials mass batching is used for lime fillers $[8,9,10]$. The investigations on possibility of applying other kinds of zeolite and on the effect of the amount of batched additive on properties of asphalt and mix asphalt are carried out [11,12]. Even though zeolite partially replaces a filler, no studies of zeolites properties with respect to their applicability as fillers are carried out.

Besides binding agents and aggregates the mineral filler is an important component of the mix asphalt. Asphalt binding agents combined with the slurry (mastic) that is a asphalt binder of changed properties dependent on both the kind of filler aggregate and asphalt. Composition and structure of mastic can be compared to natural asphalt characterized by a large content of fine mineral dust. In order to improve properties of petroleum asphalt to mix asphalt a filler aggregate is added. The filler in the mix asphalt performs numerous important functions $[13,14]$ :

- fills the void spaces between mineral mixture grains,

- stiffens asphalt forming mineral filled asphalt together with the binder which binds aggregate mix grains, 
- improves water tightness and frost proof of mix asphalt.

Performing the above functions depends on properties of the filler aggregate which are mineral composition, graining, surface area and grain shape. In the production of mix asphalt, mineral filler obtained from lime rock milling (so called lime flour) most frequently plays a role of a filler. There can be also used other materials e.g. line, mineral dust obtained from the installation of dust extraction during production of mix asphalt, flyashes from hand coal, cement dust $[15,16,17,18,19]$.

The lack of literature data about replacement of line filling material by zeolite group minerals motivated the authors to make laboratory tests which proved applicability of this type of minerals in the production of mix asphalt.

\section{Materials}

Synthetic zeolite of $\mathrm{NaP} 1$ structure type natural zeolite-clinoptilolite and a typical filler applied in the production of mix asphalt i.e lime filler were used in the studies. Synthetic zeolite was prepared by the reaction of fly-ash conversion under hydrothermal conditions in the semi-technical scale. The fly-ash used in syntheses came from conventional burning of hard coal in the Kozienice Electric Power Station. Natural zeolite (clinoptelolite) was a zeolite tuff originating from the deposit Sokyrnytsya -Transcarpathia District (Ukraine). Lime flour from Lhoist Bukowa LTD was the reference material.

The binders used in the studies were asphalt 35/50 and asphalt 70/100 produced by LOTOS Asfalt LTD.

\section{Methods of research}

Mineral composition of zeolite materials and lime flour was determined by powder diffractometry XRD using the X-ray diffractometer PanalyticalX'pert APD with the goniometer PW 3020 and $\mathrm{Cu}$ lamp as well as a graphite monochrome. The analysis was made

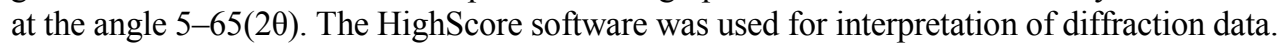

Filling material graining was measured using the laser diffraction method on the apparatus Malvern Mastersizer 2000 measuring particles in the range 0.02-2000 $\mu \mathrm{m}$. Measurements were made in the liquid dispersion using distilled water of the refractive index 1.33. Before measurement the samples were twice acted upon by ultrasounds of maximal power (total 4 minutes). Ultrasounds came from the ultrasonic depth finder of the maximal power $300 \mathrm{~W}$. The Mie theory was used for particle size calculation.

Textural properties i.e., specific surface area of micropores, pore size and distribution were determined from the adsorption/desorption isotherms of nitrogen vapour at the temperature of liquid nitrogen $\left(-194.85^{\circ} \mathrm{C}\right)$ after the sample degassing under the conditions of strictly controlled temperature $\left(250^{\circ} \mathrm{C}\right.$ for $\left.24 \mathrm{~h}\right)$ and reduced pressure $\left(10^{-3} \mathrm{hPa}\right)$. The specific surface area was determined based on the Braunauer, Emmett and Teller multilayer adsorption theory (BET) at the ratio of equilibrium pressure and nitrogen saturated vapour pressure $p / p_{0}=0.06-0.3$. The pore volume $V_{p}$ was determined from the volume of nitrogen adsorbed under the pressure $p / p_{0}=0.98$. Pore diameters were calculated from the formula $D_{p}=4 V_{p} / S_{B E T}$.

Basic physical features of fillers were determined from the norms:

- Specific density according to the norm PN-EN 1097-7 [20],

- Humidity according to the norm PN-EN 1097-5 [21],

- Specific surface area according to PN-EN196-6 [22] (according to Blaine).

The effect of zeolite addition on thermal sensitivity of asphalt was determined by penetration at $25^{\circ} \mathrm{C}$ according to the norm PN-EN 1426: 2009 [23] and softening point 
according to the norm PN-EN 1427: 2009 [24]. Due to gradual release of zeolite water, the conditioning time at $160^{\circ} \mathrm{C}$ from the time of mixing asphalt with zeolite to preparing samples was constant and it was about 30 minutes.

The penetration index was calculated from the formula:

$$
P I=\frac{20 T_{P I K}+500 \lg P-1952}{T_{P I K}-50 \lg P+120},
$$

where: $T_{P I K}$ - softening point at ${ }^{\circ} \mathrm{C}, P$ - penetration grade at $25^{\circ} \mathrm{C}, 0,1 \mathrm{~mm}$.

Dynamic viscosity was studied using the apparatus Brookfield according to the norm ASTM D4402[25] at four temperatures corresponding to those asphalt was subjected to: $60^{\circ} \mathrm{C}$ - during exploitation of the pavement, $90^{\circ} \mathrm{C}$ - during compaction of the mixture, $135^{\circ} \mathrm{C}-$ during placement and $160^{\circ} \mathrm{C}$ - during production. Each examination of viscosity of asphalt with zeolite was made on separate samples based on the principle that the time from mixing asphalt with zeolite to examination is constant and it was about 30 minutes. Given the lowest viscosity of asphalt the optimal content of both synthetic and natural zeolite was $5 \%$ in relation to the binder mass [26]. To compare the effect of various types of zeolite on properties of asphalt, there was taken $5 \%$ addition of zeolite on proportion to the binder mass.

In order to determine stiffening properties of zeolite and lime fillers, the studies were carried out on the samples of asphalt slurry. The measure of slurry stiffening was the Delta ring and ball softening point, in relation to softening point of road asphalt determined according to the norm PN-EN 13179-1 [27].

\section{Results of research}

\subsection{Characteristics of materials}

Mineral composition of some types of zeolite fillers and lime filler was determined by means of X-ray diffractometer (XRD). The diffractograms of mineral composition of natural zeolite (clinoptilolite), synthetic zeolite $(\mathrm{Na}-\mathrm{P} 1)$ and lime filler are presented in Fig. 1. The presence of zeolite phases was determined based on their characteristic interplanar distance $d_{h k l}$, for clinoptilolite the reflexes were: $8.95 ; 7.94 ; 3.36 ; 3.90 \mathrm{~A}$ and for $\mathrm{Na}-\mathrm{P} 1\left(d_{h k l}=7.10 ; 5.01 ; 4.10 ; 3.18 \mathrm{~A}\right)$.

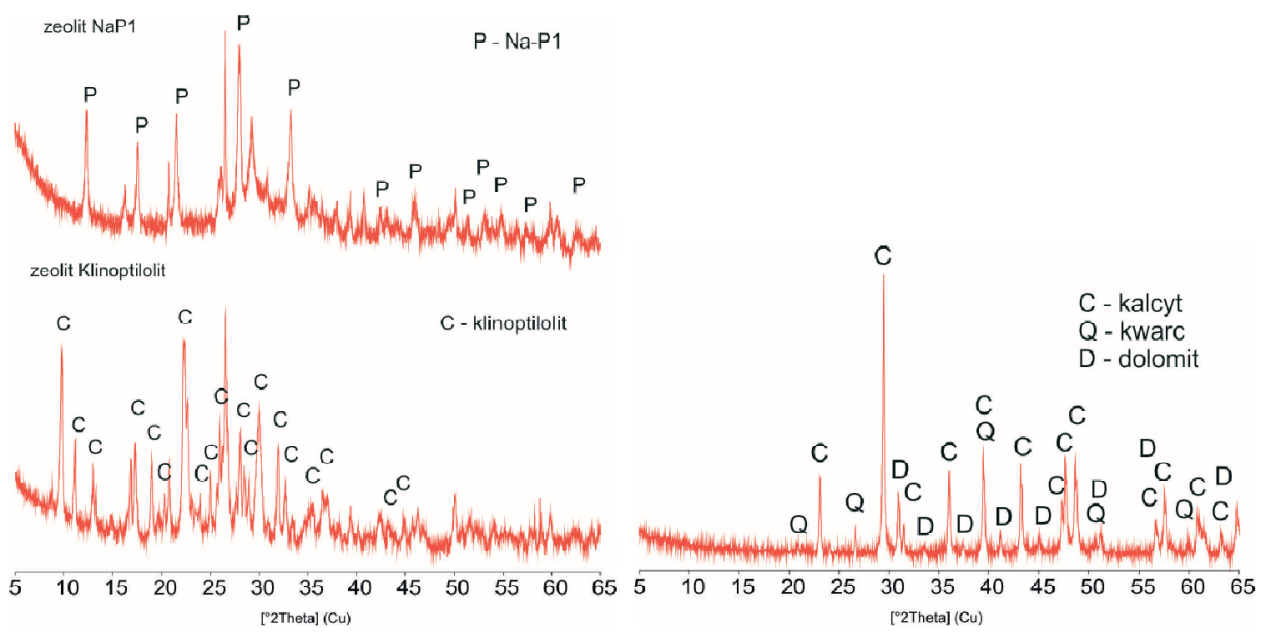

Fig. 1. Diffractograms of mineral composition a) zeolite materials b) lime filler 
The quantitative content of zeolite minerals in the filler was about $80 \%$ by volume the mineral composition of zeolite filler was completed with small amounts of opal CT, quartz and potassium feldspar for clinoptilolite [28]. Whereas in the case of synthetic materials these were mullite, quartz and unreacted fragments of aluminosilicate glaze.

The predominant component in the mineral filler composition is calcite reorganized from the main $d$-spacing $\left(d_{h k l}=3.03 ; 5.01,4.10 ; 3.18 \mathrm{~A}\right)$ accompanied trace amounts of dolomite and quartz.

Particle size distribution of the studied materials is presented in Fig. 2. The curve of zeolite $\mathrm{Na}-\mathrm{P} 1$ graining represents the modal distribution of zeolite particles with the maximum about $25 \mu \mathrm{m}$. The bimodal distribution of particle sizes is represented by clinoptilolite filler and mineral filler. In the former particles of the diameter about $300 \mu \mathrm{m}$ and $25 \mu \mathrm{m}$ are volumetrically predominant but in the latter most particles have a $25 \mu \mathrm{m}$ diameter and they are accompanied by the particles of a diameter $200 \mu \mathrm{m}$.

Studies of textural properties of zeolites showed significant differences among the fillers. The zeolite material of $\mathrm{Na}-\mathrm{P} 1$ type possesses fivefold larger specific surface area $94,48 \mathrm{~m}^{2} / \mathrm{g}$ than that of clinoptilolite which is $18.3 \mathrm{~m}^{2} / \mathrm{g}$. Synthetic zeolite has also larger contribution of mesopores compared to the natural one. Practicully all textural parameters are definitely higher for $\mathrm{Na}-\mathrm{P} 1$ compared to clinoptilolite. Lime flour is a non-porous material of a very small specific surface area $1.91 \mathrm{~m}^{2} / \mathrm{g}$. Table 1 presents the textural parameters.

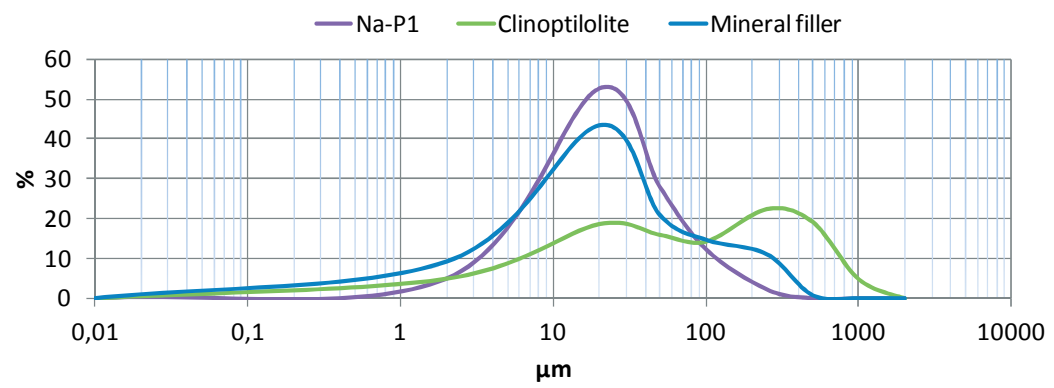

Fig. 2. Distribution of zeolite particle sizes

Table 1. Textural parameters of clinoptilolite, zeolite NaP1 and mineral filler

\begin{tabular}{|c|c|c|c|c|c|c|}
\hline Materials & $\begin{array}{c}S_{B E T} \\
2 \\
\mathrm{~m} / \mathrm{g} \\
\end{array}$ & $\begin{array}{c}V_{m i c} \\
\mathrm{~cm}^{3} / \mathrm{g}\end{array}$ & $\begin{array}{c}S_{m i c} \\
2 \\
\mathrm{~m} / \mathrm{g}\end{array}$ & $\begin{array}{c}V_{m e s} \\
\mathrm{~cm}^{3} / \mathrm{g}\end{array}$ & $\begin{array}{c}S_{m e s} \\
2 \\
\mathrm{~m} / \mathrm{g}\end{array}$ & $\begin{array}{c}D_{p} \\
\mathrm{~nm}\end{array}$ \\
\hline Clinoptilolite & 18.3 & 0.0051 & 10.65 & 0.046 & 7.68 & 10.0 \\
\hline $\mathrm{Na}-\mathrm{P} 1$ & 94.48 & 0.0048 & 10.62 & 0.233 & 85.86 & 8.9 \\
\hline Mineral filled & 1.91 & 0.000019 & 1.95 & 0.0075 & 1.65 & 18.3 \\
\hline
\end{tabular}

The other physical properties are presented in Table 2. As follows from the studies absorbability of clinoptilolite is $50 \%$ but that of the synthetic zeolite $\mathrm{Na}-\mathrm{P} 1$ is three times as high. Such large absorbability is due to large porosity of zeolite materials. Moisture content of both zeolite materials is larger than $1 \%$ and does not satisfy the requirements for fillers in mix asphalt [29]. The mineral filler is characterized by the lowest moisture content and absorbability. Both zeolite of $\mathrm{Na}-\mathrm{P} 1$ type and clinoptilolite have lower density than the lime filler. According to Blaine the specific surface area of lime flour is $4703 \mathrm{~cm}^{2} / \mathrm{g}$ and that of clinoptilolite is $5288 \mathrm{~cm}^{2} / \mathrm{g}$. No reliable results of specific surface area were obtained for the synthetic zeolite NaP1 using the Blaine method. 
Table 2. Basic physical properties of mineral filler, zeolite $\mathrm{Na}-\mathrm{P} 1$, clinoptilolite

\begin{tabular}{ccccc}
\hline Materials & Density & $\begin{array}{c}\text { Absorbability } \\
{\left[\mathrm{g} / \mathrm{cm}^{3}\right]}\end{array}$ & $\begin{array}{c}\text { Moisture } \\
\text { content } \\
{[\%]}\end{array}$ & $\begin{array}{c}\text { Specific surface area } \\
\text { according to Blaine } \\
{\left[\mathrm{cm}^{2} / \mathrm{g}\right]}\end{array}$ \\
\hline Mineral filler & 2.618 & 22 & 0.36 & 4703 \\
\hline Clinoptilolite & 2.135 & 50 & 4.4 & 5288 \\
\hline zeolit Na-P1 & 2.319 & 165 & 7.82 & Lack of results \\
\hline
\end{tabular}

\subsection{Effect of zeolite addition on asphalt properties}

The effects of zeolite addition on thermal sensitivity of asphalt are presented in Table 3. Penetration grade of asphalt $35 / 50$ with the zeolite material at $25^{\circ} \mathrm{C}$ is slightly lower than that for the reference sample whereas the softening point is insignificantly higher. Both penetration grade and softening point of asphalt with the addition of zeolite are comparable with the results obtained for asphalt $35 / 50$ and the difference is within the norm scatter of the results. Thermal sensitivity measured by means of the penetration index changes. However it is in the range of optimal values for asphalt ( from -1.0 to 1.0) in each penetration index variant.

Table 3. Properties of asphalt $35 / 50$ and asphalt $35 / 50$ with the addition of zeolite.

\begin{tabular}{cccc}
\hline Asphalt properties & $\begin{array}{c}\text { Penetration grade } \\
{[\mathrm{mm}]}\end{array}$ & $\begin{array}{c}\text { Softening point } \\
{\left[{ }^{\circ} \mathrm{C}\right]}\end{array}$ & $\begin{array}{c}\text { Penetration index PI } \\
{[-]}\end{array}$ \\
\hline $35 / 50$ & 36.5 & 55.80 & -0.56 \\
\hline $35 / 50+5 \%$ Na-P1 & 34.5 & 57.20 & -0.39 \\
\hline $35 / 50+5 \%$ Clinoptilolite & 36 & 56.60 & -0.42 \\
\hline
\end{tabular}
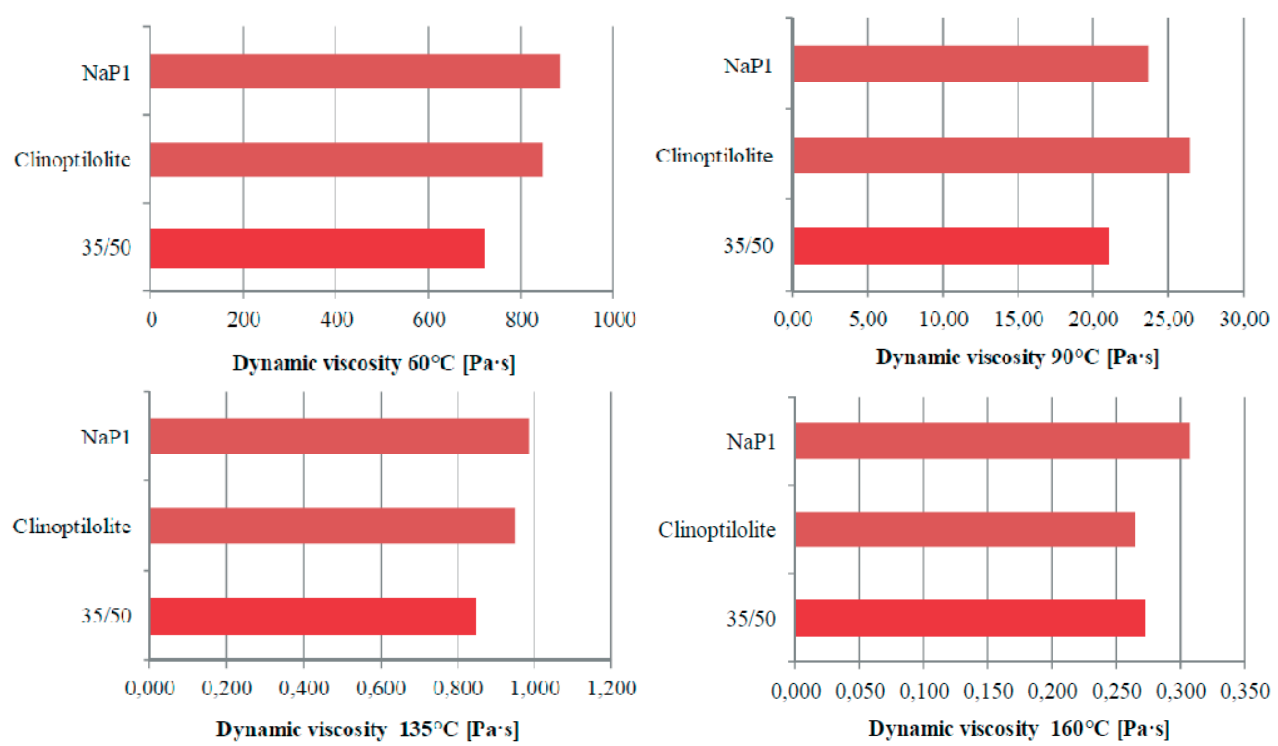

Fig. 3. Dynamic viscosity of asphalt $35 / 50$ with the addition of zeolite a) $\left.60^{\circ} \mathrm{C} \mathrm{b}\right) 90^{\circ} \mathrm{C} \mathrm{c}$ ) $135^{\circ} \mathrm{C}$ d) $160^{\circ} \mathrm{C}$

Figure 3 presents the results of dynamic viscosity studies using the Brookfield viscometer which indicate that zeolite causes asphalt viscosity increase independent of temperature. Clinoptilolite increases viscosity to a smaller extent than the synthetic zeolite 
Na-P1. At $160^{\circ} \mathrm{C}$ viscosity of asphalt with the addition of natural zeolite is lower than that of the reference sample.

Figure 4 presents the results of studies on zeolite stiffening properties. Clinoptilolite is characterized by larger stiffening action $\left(15^{\circ} \mathrm{C}\right)$ than the mineral filler $\left(9^{\circ} \mathrm{C}\right)$. Replacement of the part of mineral filler with zeolite results in the stiffening range $10.4-10.6^{\circ} \mathrm{C}$. The study with the results synthetic zeolite NaP1 was not carried out. The zeolite material "absorbed" asphalt due to large porosity of the zeolite material NaP1.

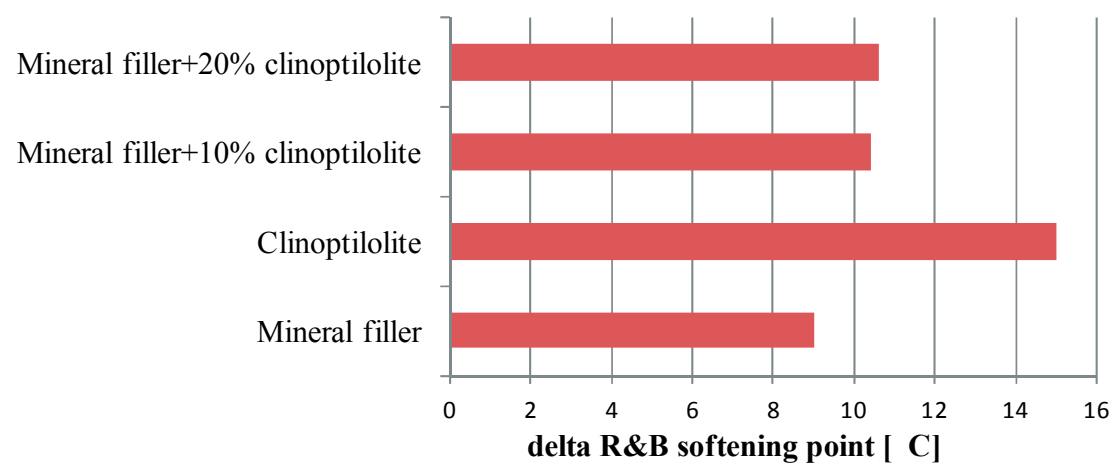

Fig. 4. Delta ring and ball softening point $\left[{ }^{\circ} \mathrm{C}\right]$

\section{Conclusions}

Zeolite material differs significantly from lime flour as regards graining, chemical composition and textural parameters. Zeolites possess large surface area and are porous materials. Based on the studies of penetration grade and softening point in can be stated that $5 \%$ addition of zeolite in relation to the asphalt mass does not have a negative effect on the thermal sensitivity of asphalt. Similar results are obtained for the natural zeoliteclinoptilolite and the synthetic one - Na-P1.

Zeolite occurs in the form of dust and after mixing with asphalt it behaves like a filler which may increase asphalt viscosity. With 5\% addition of zeolite, too small amount of water can be needed for bitumen foaming.

Studies of Delta ring and ball softening point indicate that clinoptilolite causes larger stiffening of asphalt than mineral filler. Due to large porosity and specific surface area, the synthetic zeolite of Na-P1 type can not be used as an independent mineral filler.

\section{Acknowledgement}

The authors take part in the project: "Research grants for doctoral course students working in research teams" financed by the Marshal's Office, Lublin Voivodeship.

\section{References}

1 Franus W. Characterization of X-type zeolite prepared from coal fly ash. Polish Journal of Environmental Studies 21(2) (2012) 337-343.

2 Wdowin M., Franus W., Panek R. Preliminary results of usage possibilities of carbonate and zeolitic sorbents in CO2 capture. Fresenius Environmental Bulletin 21(12) (2012) 3726-3734.

3 Chałupnik S., Franus W., Wysocka M., Gzyl G. Application of zeolites for radium removal from mine water. Environmental Science and Pollution Research 20 (2013) 7900-7906, DOI 10.1007/s11356-013-1877-5. 
4 Materiały informacyjne firmy Aspha-min, dostępne na stronie http://www.asphamin.com/98.html.

5 Deutscher Asphaltverbande.V.; Mieszanki mineralno asfaltowe o obniżonej temperaturze. Porady z praktyki do praktyki, 2009.

6 Hurley G., Prowell B. Evaluation of potential processes for use in warm asphalt mixes. Journal of the Association of Asphalt Paving Technologists 75 (2006) 41-85.

7 Barthel W., Marchand J., Von Devivere M. Warm mix asphalt by adding a synthetic zeolite. Proceedings of the $3^{\text {rd }}$ Eurasphalt and Eurobitume Conference, Book 1, Foundation Eurasphalt, Breukelen, The Netherlands, 2004, 1241-1249.

8 Kavussi A., Hicks R.G. Properties of bituminous mixtures containing different fillers. Proc Assoc Asphalt Paving Technol 66 (1997) 153-186.

9 Chen M, Lin J, Wu S, Liu C. Utilization of recycled brick powder as alternative filler in asphalt mixture. Constr Build Mater 25(4) 2011 1532-1536.

10 Faheem A.F., Hintz C., Bahia H., Al-Qadi I.L. Influence of filler fractional voids on mastic and mixture performance. Transportation Research Record: Journal of the Transportation Research Board, No. 4264, Transportation Research Board of the National Academies, Washington, D.C. 2012, 74-80.

11 Sengoz B., Ali Topal A., Gorkem C. Evaluation of natural zeolite as warm mix asphalt additive and its comparison with other warm mix additives. Construction and Building Materials 43 (2013) 242-252.

12 Kukiełka J., Woszuk A., Franus W. Mieszanki mineralno-asfaltowe o obniżonej temperaturze produkcji z dodatkiem zeolitów. Budownictwo i Architektura, 13(4) (2014) 161-168.

13 Piłat J., Radziszewski P. Nawierzchnie asfaltowe. Wydawnictwa Komunikacji i Łączności, Warszawa 2004.

14 Piłat J. Wpływ właściwości mączek mineralnych na kształtowanie cech technicznych kompozytów mineralno-asfaltowych. Wydawnictwa Politechniki Warszawskiej, Warszawa 1994.

15 Little D.N., Petersen J.C. Unique effects of hydrated lime filler on the performance-related properties of asphalt cements: physical and chemical interactions revisited. J Mater Civ Eng 17(2) (2005) 207-218.

16 Grabowski W., Wilanowicz J., Andrzejczak M., Bilski M.Warunki zastosowania popiolu lotnego jako wypetniacza do mieszanek mineralno - asfaltowych. Budownictwo i Architektura 13(1) (2014) 181-190.

17 Grabowski W., Słowik M., Wilanowicz J., Soból T. Właściwości strukturalne i funkcjonalne wypetniaczy z instalacji odpylania gazów wytwórni mieszanek mineralno-asfaltowych. Zeszyty Naukowe Politechniki Gdańskiej. Budownictwo Lądowe 60 (2006) 161-168.

18 Serkan T. Mechanical evaluation of asphalt-aggregate mixtures prepared with fly ash as filler replacement. Can J Civ Eng 35(1) (2008) 27-40.

19 Chen M., Lin J., Wu S., Liu C. Utilization of recycled brick powder as alternative filler in asphalt mixture. Constr Build Mater 25(4) (2011) 1532-1536.

20 PN-EN 1097-7. Badania mechanicznych i fizycznych właściwości kruszyw - Część 7: Oznaczanie gęstości wypetniacza - Metoda piknometryczna.

21 PN-EN 1097-5. Badania mechanicznych i fizycznych właściwości kruszyw - Część 5: Oznaczanie zawartości wody przez suszenie w suszarce $z$ wentylacją.

22 PN-EN 196-6. Metody badania cementu - 6: Oznaczanie stopnia zmielenia.

23 PN-EN 1426:2009. Asfalty i lepiszcza asfaltowe - Oznaczanie penetracji igła.

24 PN-EN 1427:2009. Asfalty i lepiszcza asfaltowe - Oznaczanie temperatury mięknienia - Metoda Pierścień i Kula.

25 ASTM D 4402. Standard Test Method for Viscosity Determination of Asphalt at Elevated Temperatures Using a Rotational Viscometer.

26 Sengoz B., Ali Topal A., Gorkem C. Evaluation of natural zeolite as warm mix asphalt additive and its comparison with other warm mix additives. Construction and Building Materials 43 (2013) 242-252.

27 PN-EN 13179-1. Badania kruszyw wypetniajacych stosowanych do mieszanek bitumicznych Część 1: Badanie metoda pierścienia delta i kuli. 
28 Franus W., Dudek K. Clay minerals and clinoptilolite of Variegated Shales Formation of the Skole Unit. Polish Flysch Carpathians. Geologica Carpathica 50 (1999) 23-24.

29 Kruszywa do mieszanek mineralno-asfaltowych $i$ powierzchniowych utrwalen na drogach krajowych. Wymagania techniczne WT1 2010. 